\title{
An investigation into the influence of Corporate Social Responsibility disclosures on the satisfaction level of employees during COVID-19 times: Evidences from Multinational Corporations in UAE
}

\author{
${ }^{1}$ Sarwat Jahan, ${ }^{2}$ Sidra Abid \\ ${ }^{1}$ Department of Business and Accountancy, Lincoln University College, Main Campus, Selangor, \\ Malaysia \\ ${ }^{2}$ School of Management, Universiti Sains Malaysia \\ *Corresponding author: sarwat_usman@hotmail.com
}

\begin{abstract}
The purpose of this research is to present empirical findings related to the impact of CSR on the job satisfaction level of employees during the Pandemic times, especially in reference to the case of multinational corporations operating within the boundaries of United Arab Emirates. In this context, the factor of CSR was further categorised into three essential constructs of philanthropic responsibilities, environmental responsibilities, and welfare of general public. In reference to the methodological choices, the study has undertaken quantitative research design, which has been supported through the use of positivist philosophy and deductive approach. In addition, the study has collected primary data from a total of 250 employees through questionnaire, which had a total of 5 sections including; demographics, philanthropic responsibility, environmental responsibility, welfare of general public, and employee satisfaction. The study found that employee satisfaction had strongly positive (uphill) linear relationship with the variables of philanthropic responsibilities and environmental responsibilities. The study further elaborated that the organizational philanthropy in the era of Covid-19 has significantly positive impact on the satisfaction levels of employees.
\end{abstract}

Keywords: 2019 novel coronavirus disease (COVID-19), Corporate Social Responsibility, job satisfaction level of employees, public welfare, Multinational corporations in UAE

Article Received: 10 August 2020, Revised: 25 October 2020, Accepted: 18 November 2020

\section{INTRODUCTION}

The 2019 novel coronavirus disease (COVID-19) has caused a sudden outbreak of pneumonia. The World Health Organization has declared a public health emergency. The disease has posed great risks and challenges to the world's economic and social development (Ding et al. 2020). Based on past experience of major disasters, enterprises take the initiative to carry out their social responsibilities, quickly resolve their difficulties as it is directly related to enterprises' future development in the postpandemic era. These actions will have a profound impact on the brand image as well as on the employees motivation and satisfaction level of enterprises. Enterprises' active disclosure of their corporate social responsibility (CSR) activities through social media can affect advertising and improve enterprise image and performance (Gong et al. 2018).

Corporate social responsibility (CSR) has been consistently recognised and acknowledged as the process that encourages an organisations to work for the development and progress of communities in which it operates in. For the very reason, studies conducted in reference to CSR has indicated that companies have considered it amongst their priorities, and have even embed the concept into their business strategy; for instance, the study conducted by Vinerean et al. (2013) shed light on the fact that the failure to work on CSR activities can lead to dramatic failure of the businesses, as both customers and employees have developed the perception that it is the foremost responsibility of the companies to invest their time and resources into the communities and societies.

A study conducted by Stawiski et al. (2010), in this domain, shed light on the importance of CSR activities, and stated that since companies operate in an intensely competitive business environment, undertaking CSR activities can yield positive results for the business. In particular, the study shed light on some companies that achieved their desired height of success by working for the progress and development of the communities, and as a result, it resulted in the formation of positive attitude and behaviour towards the organisation, while giving employees a sense to feel proud for the organisation they 
work for. This ultimately resulted in higher job satisfaction, morale, and engagement levels; not only this, it also helped the organisations to retain and sustain their employees to remain dedicated and loyal to the business and its core operations for longer-duration, rather than to search for companies that have better CSR activities.

The $21^{\text {st }}$ century has experienced a radical and fundamental change in reference to CSR, and has become the centre of attention for both academicians and multinationals. In particular, an abundance of literature is available related to the importance of CSR activities and its role in the overall growth and success of multinational companies; however, these studies have not yet presented the overall importance of CSR factors of philanthropic responsibility, environmental responsibility, and welfare of the general public in greater detail. This implies that there exists a gap in the literature that must be immediately filled to ensure that readers can develop a better understanding of the role of CSR in the growth of MNCs, in the $21^{\text {st }}$ century.

Corporate social responsibility has gained an everincreasing attention from both academicians and policy makers, and this can be primarily attributed to its overall impact on the company's performance and productivity, which is why more and more companies have changed their attitude and perception towards CSR, and have integrated it into their business strategies. Similarly, studies have even found that companies that have engaged in CSR activities have experienced boosted morale and loyalty to the organisation they work for, but insufficient information has been presented in reference to the constructs of CSR (i.e. philanthropic responsibility, environmental responsibility, and welfare of the general public). This implies that this gap must be immediately addressed to further help the policy makers and institutions to capitalise upon CSR for better job satisfaction of employees. Considering the latter, the purpose of this investigation is to present empirical findings related to the impact of CSR on the satisfaction level of employees, especially in reference to the case of multinational corporations operating within the boundaries of United Arab Emirates.

The objectives of the study are as follows;

- To discuss the relevance and significance of corporate social responsibility in the age of Covid-19 within the context of multinational corporations operating in UAE.

- To investigate the role of multinational corporations in terms of social responsibility, philanthropy, and welfare work in UAE during the Pandemic.

- To investigate the impact of corporate social responsibility (i.e. philanthropy, environmental responsibility, and welfare) on the satisfaction levels of employees working in multinational corporations of UAE.

To investigate the impact of perceived enterprise selfsacrifice on the satisfaction level of employees during the Covid-19 times.

\begin{tabular}{|c|c|c|}
\hline $\begin{array}{l}\text { CSR activities in MNCs } \\
\text { under Covid } 19 \\
\text { - } \text { Philanthropic } \\
\text { - Environmental } \\
\text { - Welfare of General } \\
\text { public }\end{array}$ & $\begin{array}{c}\text { Perceived } \\
\text { Organizational's self } \\
\text { sacrifice }\end{array}$ & Employee Satisfaction \\
\hline
\end{tabular}

\section{Conceptual Framework}

In reference to the significance, it can be argued that the significance of this research is two-fold. At one end, the study has presented theoretical knowledge in the preliminary review of literature, where the concept of CSR activities have been critically investigated during the Pandemic, and reflected in the constructs of philanthropic responsibility, environmental responsibility, and welfare of general public; meanwhile the study has also presented the concept of employee satisfaction as a result of CSR activities. On the other hand, the study has also presented empirical findings through the use of different statistical tests, as this is considered to be the most authentic and credible way of presenting the findings.

\section{LITERATURE REVIEW}

Existing research on the impact of catastrophic shocks such as Pandemics on MNCs mainly includes the following. First, such shocks will cause certain material losses. Basker and Miranda (2014) use census data from the US and find that the survival conditions of enterprises are directly proportional to the material losses as a result of catastrophic shocks such as floods and earthquakes. Besides, the more serious the shock is, the higher the exit rate. Second, some catastrophes also affect the commercial property of MNCs, such as inventory and equipment. Further, MNCs' order fulfillment and future sales are affected, an important reason for their bankruptcy or business recovery. Additionally, catastrophes such as Pandemics impact the labor market and the upstream and downstream of the industrial chain. Therefore, the loss of employees and customers is an important factor affecting the recovery of enterprises (Corey and Liu et al. Frontiers of Business Research in China (2020). However, the impact of COVID-19 on MNCs has manifested in the uncertainty of the pandemic. 
The number of cases in developed economies in Europe and the US has been climbing; therefore, the global supply and industrial chains have been blocked. The uncertainty in MNCs' operations has increased. Meanwhile, the decline in investors' risk tolerance has led to financing difficulties for MNCs, increasing their liquidity and debt default risks, and intensifying the fluctuation in economic operation.

In summary, COVID-19 is special, and Pandemic prevention measures such as lockdowm have effectively prevented and controlled its spread; however, the real economy has been temporarily suspended. MNCs are faced with operational difficulties and are concerned with surviving this crisis. Under the present Pandemic situation, MNCs focus on saving themselves by attracting consumers and quickly converting their products into cash flow. Therefore, the process of MNCs fulfilling their CSR to gain consumer recognition and favor to in order to overcome this crisis is a challenge that all MNCs must tackle urgently.

CSR disclosure refers to the concept, strategy, and methods by which enterprises fulfill their CSR, the direct and indirect impacts, and the achievements and deficiencies caused by their business activities in the economic, environmental, and social fields. In other words, it involves the display and reporting of information (Stuart et al. 2020). The disclosure of CSR activities by large global enterprises, through CSR annual reports and mainstream media reports, has become a common practice (Muslu et al. 2019). The CSR report is an important nonfinancial information disclosure carrier and communication platform between the enterprise and stakeholders (Stuart et al. 2020).

The CSR includes innovations related to education, occupational health and lifelong learning (Schwartz, 2017). On the other hand, corporate social responsibility means that the company cares for the well-being of its employees in a way that goes beyond the minimum requirements defined by law (Matten and Moon, 2004). According to Lindgreen and Swaen (2010), social responsibility can also be reflected in the company's efforts to ensure human rights and the employment of people who are at risk of exclusion. In general, CSR includes the actions that a company does without a legal requirement and without economic reasons obliging the company to act in that way - namely, voluntary actions and the company's desire to act responsibly (Lai et al., 2010). On the other hand, social responsibility is not charity either, but rather the way a business takes into account the impact of its own activities on both the various stakeholders and the surrounding society. The principles of sustainable development can be considered as pioneers of solidarity.

The philanthropic heart in the society strikes faster than ever before. Studies prove that more and more people, families and companies are initiating initiatives that serve the public interest (Cadbury, 2006). The way in which philanthropy is done also evolves include from digital philanthropy to expertise patronage, everyone contributes to a better society in his or her way (Crane and Matten, 2007). Although corporate social responsibility is more than the polishing of corporate image, $61 \%$ of business executives have been held by the Central Chamber of Commerce as a very important motive for responsible activity, its impact on the company's image and reputation. Responsibility is also motivated by long-term economic benefits and the competitive advantage that is achieved by competing in competing with customers and the workforce (Carroll, 2015). However, the strongest motive for responsible activity was the interest of the company's management and the owners.

Corporate social responsibility was considered more important in large than small businesses (Roy et al., 2015). The importance of the neighbourhood was emphasised in the operations of small companies. Business leaders considered it particularly important to be accountable for the products and services of the company, as well as for compliance with laws and norms (Carroll, 1991). Important business executives also considered responsibility for the financial viability of the operation. Responsibility for staff welfare was seen as an important part of the company's social responsibility.

The development of corporate social responsibility and the employment of disadvantaged people can be approached from many directions (McWilliams, 2015). On the one hand, the emphasis can be on the means of professional rehabilitation and the effectiveness of different means, and on the other hand, the relationship between enterprises and social responsibility can be explored as a separate business model and to explore the extent to which the disadvantaged problems have become independent in corporate social responsibility strategies and practices (Bhattacharya et al., 2017).

Environmental responsibility includes activities including, the fight against climate change, the protection of waters, air and soil, and the economical use of natural resources. The company's operations should save resources and respond to product life cycle (Grayson and Hodges, 2017). As production methods and technology evolves, industrial and energy production emissions to water, soil and air have declined decisively over the last twenty years. Developments have been guided by the requirements of environmentally aware customers and consumers alongside the tightening of environmental regulations (Cheng, Ioannou and Serafeim, 2014). The companies' own desire to manage the environment has also increased. Environmental issues are becoming an important competitive factor; products will be better traded if the manufacturing company carries responsibility for the environment as well (Zentes, Morschett and SchrammKlein, 2017). Demand for environmentally-friendly products and technologies is growing strongly and the manufacturing industry is a major employer in the future. According to Belal (2016), the most difficult aspect of 
social responsibility is social responsibility. The European Commission includes social responsibility, such as innovations in workplace health, education and lifelong learning. Social responsibility includes, in particular, issues related to working life, staff and society (Kesharwani and Ravipati, 2015). These include employee well-being and know-how, working conditions, product safety and good practices. Many companies and external stakeholders consider it completely natural and aimed at making the company bear social responsibility beyond what is required by law (Manchanda, 2017). Companies are now being subjected to social responsibility more strongly than before (Jones Christensen, Mackey and Whetten, 2014).

The employee satisfaction describes the attitude of an employee on his work environment (Alegre, MasMachuca and Berbegal-Mirabent, 2016). There is an internal comparison between what a person expects from their work environment and what they actually find. The term employee satisfaction is used primarily in business administration (Koys, 2001). The work and organisational psychology used synonymous with employee satisfaction, the term job satisfaction. The employee satisfaction analysis measures how employees and executives are emotionally attached to the business. Measurement of employee satisfaction is not an issue in itself, but from a managerial and internal communication tool, whose skilful use can affect employees' attitudes towards the organisation and their work (Edmans, 2011). Satisfaction in itself, however, does not mean that employees have a daily work experience that they enjoy doing their job or that they are fans of an organisation.

Job satisfaction or dissatisfaction is closely linked to the loyalty of employees, as well as to the cost of wage or salary (Madlock, 2008). Satisfied employees are more loyal and less likely to be. Dissatisfied workers are, however, looking around the labour market, lagging behind and asking for more wages to compensate for disturbing situations. According to the report, the units remaining on their budget targets had been clearly inferior to management ratings than the units that had achieved the targets (Chen et al., 2006). In the personnel survey, leadership was a problem in both weak management and business culture. Deficiencies were found, for example. communication with superiors, knowledge of their own and company goals, and rewarding (Parvin and Kabir, 2011).

Loyalty is most likely to increase satisfaction with the organisation of work processes, career opportunities within the organisation and opportunities for job development. Satisfaction benefits also increase loyalty from other factors, but dissatisfaction with the benefits does not play a role as a push factor in leaving the job, such as relationships (Matzler and Renzl, 2006). The underlying reason for this breakdown is the basic observation of the psychological well- being research that it is best to look at feelings on two axes, in addition to the positive and negative factors, as well as the degree of activation. By combining these two dimensions, we have four different basic dimensions in which man can work: rest, stress, satisfaction and job suction. Satisfaction and satisfaction are both low levels of activation, but a welcoming employee has a positive attitude towards his work (Jun, Cai and Shin, 2006).

Many HR managers still seem to be at a loss as to how such a bond can be achieved. Cash bonuses are often seen as part of the salary and lose their effect in conjunction with the total salary - a long-term motivation gain is missing. In addition to general attractiveness factors such as remuneration and working conditions, work content or development perspectives can act as motivators (Bauman and Skitka, 2012).

For some companies, social responsibility development is more like a business case that is polished on the surface, while some companies want corporate responsibility to genuinely develop their business (Jamali and Karam, 2018). Businesses believe in their own business and responsible operations to benefit from the long-term. The implementation of corporate social responsibility can eliminate the risks involved and thus influence the image of the company more far (Moon and Knudsen, 2018). Although taking into account organisational stakeholder considerations is essential in developing corporate social responsibility, it emphasises the importance of responsible business operations for the company's own operations and staff. Corporate social responsibility is a strong motive for the company's operations: responsible business activity increases the sense of work and the staff's pride in the company's own business (Pedersen, 2015).

In addition to corporate responsibility, concepts of corporate responsibility and corporate citizenship have also been used (Crane and Matten, 2007). The starting point in thinking about corporate responsibility is that companies also have a responsibility for the local environment and different stakeholders. Corporate social responsibility is usually referred to as a liability that goes beyond law, that is to say, a form of business responsibility that goes beyond legal minimum requirements. Social responsibility refers to the company's responsibility for its employees and the surrounding environment (Jamali and Karam, 2018). This includes, for example, the development of working conditions and antidiscrimination measures. Social responsibility can also be seen in charity participation. One form of corporate social responsibility can be the employment of people with disabilities or (development) disabilities (Grayson and Hodges, 2017). Companies have developed a variety of reporting systems, recommendations and indicators to show their own social responsibility. Most of the reporting is focused on environmental responsibility.

It should be noted that strategic communication about CSR activities is still weak. The opportunities and image potential offered by CSR to companies are hardly 
exhausted (Kitada and Ölçer, 2015). The most used tool is corporate reporting, be it in the form of sustainability reports, social reports or chapters of the classic annual report. Dialogue-oriented measures in the form of meetings, public discussions or presentations on the other hand are rather rare. One reason is certain that many companies have not yet established and implemented CSR strategies, another that companies fear that they will be unjustifiably exposed to critical scrutiny and criticism by the media and the public through an open discussion of their CSR activities (Morsing and Perrini, 2009).

The importance of corporate social responsibility has changed in recent years. A few years ago, Corporate Social Responsibility was limited to social responsibility in the regional environment of a company (Saeidi et al., 2015). CSR, on the other hand, has expanded according to the European Commission's Green Paper. In addition to social responsibility, an environmental dimension has been added. Modern understanding also adds to the economic dimension (Matten and Moon, 2004). CSR activities should create a generable system that retains its essential properties and can naturally regenerate its existence. The ecological component is therefore essential and cannot be compensated by the social component (Cadbury, 2006). It depends on the way of doing business and not on which social projects the company promotes afterwards with the profit (Cheng, Ioannou and Serafeim, 2014).

The reputation of the company has a significant impact on its value, and a reputable company attracts the best employees (Cheng, Ioannou and Serafeim, 2014). Investors also see a risk of irresponsibility, which undermines the company's financing potential. In the area of employer attractiveness, employee retention and employee satisfaction, CSR is an important key element, as a study by Singhapakdi et al. (2015) confirmed. There was a significant positive correlation between CSR and employee retention, as well as between CSR and company performance. Activities such as social and environmental engagement, respect for the well-being of the workforce, the inclusion and fulfilment of community needs, as well as the environmentally conscious production of quality products raised employees' morale and motivation and making them feel committed to the company (Berad, 2011).

The impact of Corporate Social Responsibility (CSR) on (potential) employees has been poorly researched so far. (Dawkins and Lewis, 2003) CSR aims for a sustainable corporate strategy that reconciles ecology, economy and social issues. Often, the positive external impact of CSR measures is discussed; CSR can also increase the attractiveness of a company internally and help to attract and retain employees (Rettab, Brik and Mellahi, 2009). It is therefore important that measures such as corporate social and personnel policy are not taken in isolation, but are an element of a long-term corporate strategy. Only then an investment in the CSR pillar "Social" to increase the employer attractiveness sustainable and brings the companies also a demonstrable economic advantage ( Du, Bhattacharya and Sen, 2010).

\section{RESEARCH METHODOLOGY}

According to Smith, (2012), a research methodology is a systematic procedure for identifying, selecting, processing and analysing information collected for the study. The research methodology section ensures that the whole research is valid and reliable. In the current study, a research methodology is drafted to understand the impact of corporate social responsibility (CSR) on the satisfaction level of employees working in multinational corporations of UAE.

There are certain beliefs that a researcher has regarding how the data for the research is gathered, interpreted, analysed and utilised (Howell, 2012). This belief is termed a research philosophy. Epistemology and Doxology are the two important concepts that need to be understood while choosing the research philosophy. A "known to be the truth" is known as Epistemology (Martin, 2014), whereas Doxology is the "belief to be the truth" (Parsons, 2015). The journey of transforming Doxology to Epistemology under an appropriate research approach and research philosophy is the main aim of any research.

There are four types of research philosophies, namely, positivism, realism, interpretivism, and pragmatism. The research philosophy suitable for the current study is positivism. The reason to choose positivism for the current study is that it is inclined to use the statistical calculations to conclude determining the relation between independent variable, i.e. CSR and the dependent variable, i.e. employee satisfaction. The use of positivism will help to answer the main research question, i.e. the impact of corporate social responsibility (CSR) on the satisfaction level of employees working in multinational corporations of UAE from an objective viewpoint rather than a subjective viewpoint.

Since the current research is utilising positivism. Therefore, the best research strategy for the study will be deductive research. This approach will help the researcher to specify the general information available regarding the research question, hence, allowing the researcher to generate a better and concise hypothesis (Sekaran and Bougie, 2016). Another reason to choose this strategy over the others is that it will ensure that the overall study complies with the research objectives.

For the current study, the best-suited method alongside the positivism and deductive approach is a quantitative method. According to Saunders et al. (2009), a research method should be chosen based on the research approach and philosophy. Hence, a quantitative methodology will help to give the results in a quantifiable manner. Also, representing the numeric values in the forms of responses regarding the CSR activities and employee satisfaction upon which the hypothesis will either be approved or rejected. 
Measurement tools to utilised to collect the data for the research is known as a research instrument (Birmingham and Wilkinson, 2003). Scales, questionnaire, interviews, etc. are few of the types of measurement tools. The current study utilises both the primary data collection and the secondary one. To collect primary data for the study, a 5-point Likert scale-based questionnaire will be filled by the participants. The research questionnaire contains all the necessary questions that are required to answer the main research question. A 5-point Likert scale will have 5 options where $1=$ strongly agree, $2=$ agree, $3=$ neutral, 4 $=$ disagree, and $5=$ strongly disagree. This 5 -point Likert scale will ensure that the positive and negative impacts of the study are easily calculated. The secondary data will be extracted from authentic journals, articles, newspapers, books and published papers.

Regarding the current study, a non-probability sampling will be used. Non-Probability sampling is the one that does not give equal chances of selection to the individuals present in the study (Wolf et al., 2016). The reason to choose this sampling is that the sample size is large, i.e. 250 respondents. Hence, to save time and bring better results this sampling will be used. The chosen sampling technique for the study is a convenience sampling technique. According to Etikan, Musa, and Alkassim, (2016), the convenience sampling technique helps to collect data from the population that is readily available. The reason for choosing the convenience sampling technique is that it saves much time on the data collection and hence, more time can be given to the data analysis.

A total of 250 respondents were taken into consideration for filling the questionnaire. These 250 respondents were emailed the questionnaire after taking their utmost consent and answering all their questions regarding their information privacy and confidentiality. The consent form also informed the respondents how their information would be used during the study. A consent form was signed first by the respondents then the questionnaire was emailed to them.

The current study utilises quantitative research method; therefore, SPSS will be used to analyse the data. The current study aims to find the impact of CSR on the employee satisfaction in the UAE specifically. Therefore, frequency analysis, descriptive statistics, correlation analysis, and regression analysis have been carried out. In particular, the relationship and strength of association between the variables have been tested through correlation analysis whereas the element of impact has been tested through regression analysis.

\section{RESULTS}

The findings of this research have been presented in tabular and graphical forms to help the readers comprehend the findings, in addition to understand the overall impact of CSR activities on the satisfaction level of employees in the Covid-19 age, especially in reference to multinational corporations operating in United Arab Emirates.

Demographic Analysis

Table 4.1.1.

Gender

\begin{tabular}{lrr|r|r|r} 
& \multicolumn{2}{c}{ Gender } & \multicolumn{2}{c}{ Cumulative } \\
& & Frequency & Percent & Valid Percent & \multicolumn{1}{c}{ Percent } \\
\hline \multirow{2}{*}{ Valid } & 125 & 50.0 & 50.0 & 50.0 \\
\cline { 2 - 6 } & Male & 125 & 50.0 & 50.0 & 100.0 \\
\cline { 2 - 6 } & Female & 250 & 100.0 & 100.0 & \\
\hline
\end{tabular}

The questionnaire was distributed to a total of 250 participants (employees) from multinational companies operating in United Arab Emirates, and found that 50 per cent of the employees that completely filled the questionnaire were males; meanwhile the remaining 50 per cent were females. By reflecting on the gender of the participants, it can be argued that the study has considered the inclusion of both genders, rather than restricting the study to just one gender

Table 4.1.2.

\begin{tabular}{|c|c|c|c|c|c|}
\hline \multicolumn{6}{|c|}{ Age } \\
\hline & & Frequency & Percent & Valid Percent & $\begin{array}{l}\text { Cumulative } \\
\text { Percent }\end{array}$ \\
\hline \multirow[t]{6}{*}{ Valid } & $20-25$ Years & 44 & 17.6 & 17.6 & 17.6 \\
\hline & 26-30 Years & 53 & 21.2 & 21.2 & 38.8 \\
\hline & $31-35$ Years & 58 & 23.2 & 23.2 & 62.0 \\
\hline & $35-40$ Years & 48 & 19.2 & 19.2 & 81.2 \\
\hline & $40+$ Years & 47 & 18.8 & 18.8 & 100.0 \\
\hline & Total & 250 & 100.0 & 100.0 & \\
\hline
\end{tabular}

In this context, 44 employees were in the age range of 2025 years, 53 employees were in the age range of 26-30 years, 58 employees were in the age range of 31-35 years, 48 employees were in the age range of 35-40 years, and lastly 47 employees were in the age range of $40+$ years.

Table 4.1.3.

Qualification

\begin{tabular}{|c|c|c|c|c|c|}
\hline & & Frequency & Percent & Valid Percent & $\begin{array}{c}\text { Cumulative } \\
\text { Percent }\end{array}$ \\
\hline \multirow[t]{4}{*}{ Valid } & Graduate & 77 & 30.8 & 30.8 & 30.8 \\
\hline & Post Graduate & 96 & 38.4 & 38.4 & 69.2 \\
\hline & Masters & 77 & 30.8 & 30.8 & 100.0 \\
\hline & Total & 250 & 100.0 & 100.0 & \\
\hline
\end{tabular}

The demographic questions also included the element of education, and found that 77 employees held graduate degree, 96 employees had post-graduate degree, and the remaining 77 employees had master's degree. This implies that the participants considered for the study were well-educated, which means that the findings are reliable and can be considered for further investigation.

Table 4.1.4.

YearsOfExperience

\begin{tabular}{ll|r|r|r|r} 
& & & & \multicolumn{2}{c}{ Cumulative } \\
Valid & Frequency & Percent & Valid Percent & \multicolumn{1}{c}{ Percent } \\
\hline \multirow{4}{*}{ 1-3 Years } & 37 & 14.8 & 14.8 & 14.8 \\
\cline { 2 - 7 } & 4-6 Years & 49 & 19.6 & 19.6 & 34.4 \\
\hline 6-8 Years & 64 & 25.6 & 25.6 & 60.0 \\
\hline 8-10 Years & 43 & 17.2 & 17.2 & 77.2 \\
\hline 10+ Years & 57 & 22.8 & 22.8 & 100.0 \\
\hline Total & 250 & 100.0 & 100.0 & \\
\hline
\end{tabular}


For this study, 37 employees had 1-3 years of experience in the respective field, 49 employees had 4-6 years of experience in the respective field, 64 employees had 6-8 years of experience in the respective field, 43 employees had 8-10 years of experience in the respective field, and 57 employees had $10+$ years of experience.

\section{Correlation Analysis}

Correlation analysis was conducted to demonstrate the strength of association between the variables and the nature of their relationship. In this context, the correlation analysis found that there exist strongly positive (uphill) linear relationship between philanthropic responsibility and other variables of environmental responsibility, welfare, and employee satisfaction. In particular, the decision related to the strong strength of association was reached based on the Pearson Correlation values of 0.954 , 0.959 , and 0.951 respectively; whereas the positivity was deduced from the sig. (2-tailed) value of 0.000 for each variable.

Table 4.2.1

Correlations

\begin{tabular}{|c|c|c|c|c|c|}
\hline & & Philanthropy & $\begin{array}{l}\text { Environmental } \\
\text { Responsibility }\end{array}$ & Welfare & $\begin{array}{c}\text { Employee } \\
\text { Satisfactio } \\
n\end{array}$ \\
\hline \multirow[t]{3}{*}{ Philanthropy } & Pearson Correlation & 1 & $.954^{*}$ & $.959^{*}$ & $.951^{*-}$ \\
\hline & Sig. (2-tailed) & & .000 & .000 & .000 \\
\hline & $\mathrm{N}$ & 250 & 250 & 250 & 250 \\
\hline \multirow[t]{3}{*}{ Environmental Responsibility } & Pearson Correlation & $.954^{*}$ & 1 & $.963^{*}$ & $.961^{*}$ \\
\hline & Sig. (2-tailed) & .000 & & .000 & .000 \\
\hline & $\mathrm{N}$ & 250 & 250 & 250 & 250 \\
\hline \multirow[t]{3}{*}{ Welfare } & Pearson Correlation & $.959^{*}$ & $.963^{*}$ & 1 & $.951^{*}$ \\
\hline & Sig. (2-tailed) & .000 & .000 & & .000 \\
\hline & $\mathrm{N}$ & 250 & 250 & 250 & 250 \\
\hline \multirow[t]{3}{*}{ Employee Satisfaction } & Pearson Correlation & $.951^{*}$ & $.961^{*}$ & $.951^{*}$ & 1 \\
\hline & Sig. (2-tailed) & .000 & .000 & .000 & \\
\hline & $\mathrm{N}$ & 250 & 250 & 250 & 250 \\
\hline
\end{tabular}

In reference to the variable of environmental responsibility, the study also found that the variable had strongly positive (uphill) linear relationship with philanthropic responsibilities, welfare, and employee satisfaction. In particular, the decision related to the strong strength of association was reached based on the Pearson Correlation values of $0.954,0.963$, and 0.961 respectively; whereas the positivity was deduced from the sig. (2-tailed) value of 0.000 for each variable. On the other hand, the variable of welfare showed demonstrated strongly positive (uphill) linear relationship with hilanthropic responsibilities, environmental responsibilities, and employee satisfaction. In particular, the decision related to the strong strength of association was reached based on the Pearson Correlation values of 0.959, 0.963, and 0.951 respectively; meanwhile the positivity was deduced from the sig. (2-tailed) value of 0.000 for each variable. The last variable for the correlation analysis was the employee satisfaction and it also demonstrated strongly positive (uphill) linear relationship with the variables of philanthropic responsibilities, environmental responsibilities, and welfare. In particular, the decision related to the strong strength of association was reached based on the Pearson Correlation values of 0.951, 0.961, and 0.951 respectively; meanwhile the positivity was deduced from the sig. (2-tailed) value of 0.000 for each variable.

\section{Regression Analysis}

Regression analysis, in this study was conducted to demonstrate the overall impact of CSR activities and its constructs of philanthropic responsibilities, environmental responsibilities, and welfare against employee satisfaction. In this context, the first statistical test conducted was the model summary, which helps in explaining the overall capabilities of the independent variables to explain the variations in dependent variable. From the following graphical representation, it became evident that the R Square value was 0.938 , which suggests that the predictors of philanthropic responsibilities, environmental responsibilities, and welfare can elaborate and explain 93.8 percent of the variations in the employee satisfaction levels.

Table 4.3.1

\begin{tabular}{|c|c|c|c|c|}
\hline \multicolumn{5}{|c|}{ Model Summary } \\
\hline Model & $\mathrm{R}$ & R Square & $\begin{array}{l}\text { Adjusted R } \\
\text { Square }\end{array}$ & $\begin{array}{l}\text { Std. Error of the } \\
\text { Estimate }\end{array}$ \\
\hline 1 & $969^{9}$ & .938 & .938 & .34058 \\
\hline
\end{tabular}

a. Predictors: (Constant), Welfare, Philanthropy, Environmental Responsibility

The second statistical test that was conducted in relation to the regression analysis was Analysis of Variance (ANOVA), which helps in explaining the fitness of the regression model. From the following graphical representation, it has become evident that the significance value was 0.000 , which is considered to suggest that the regression model is fit for analysis. 
Table 4.3.2

\begin{tabular}{|c|c|c|c|c|c|c|}
\hline \multicolumn{7}{|c|}{ ANOVAa } \\
\hline Model & & Sum of Squares & df & Mean Square & $\mathrm{F}$ & Siq. \\
\hline \multirow[t]{3}{*}{1} & Regression & 433.967 & 3 & 144.656 & 1247.086 & $.000^{b}$ \\
\hline & Residual & 28.535 & 246 & 116 & & \\
\hline & Total & 462.502 & 249 & & & \\
\hline
\end{tabular}

a. Dependent Variable: Employee Satisfaction

b. Predictors: (Constant), Welfare, Philanthropy, Environmental Responsibility

The last statistical test is of Coefficient, which helps in explaining the impact of independent variables, on individual basis, on the dependent variable. The significance value is very important, as value greater than 0.05 implies that the variable has no significant impact on the dependent variable. Judging from the significance value, as mentioned in the following table, it has become evident that philanthropy has significantly positive impact on the satisfaction levels of employees; meanwhile the beta value has indicated that 1 unit change in philanthropic responsibilities can lead to 30.1 percent change in the overall satisfaction level of employees.

Table 4.3 .3

\begin{tabular}{|c|c|c|c|c|c|c|}
\hline \multicolumn{7}{|c|}{ Coefficients } \\
\hline \multirow[b]{3}{*}{ Model } & & \multirow{2}{*}{\multicolumn{2}{|c|}{ Unstandardized Coefficients }} & \multirow{3}{*}{$\begin{array}{c}\text { Standardized } \\
\text { Coefficients } \\
\text { Beta }\end{array}$} & \multirow[b]{3}{*}{$\mathrm{t}$} & \multirow[b]{3}{*}{ Sig. } \\
\hline & & & & & & \\
\hline & & $\mathrm{B}$ & Std. Error & & & \\
\hline \multirow[t]{4}{*}{1} & (Constant) & -.018 & .045 & & -.402 & .688 \\
\hline & Philanthropy & .301 & .063 & .293 & 4.805 & .000 \\
\hline & Environmental Responsibility & .512 & .067 & .495 & 7.691 & .000 \\
\hline & Welfare & .199 & .070 & .194 & 2.846 & .005 \\
\hline
\end{tabular}

a. Dependent Variable: Employee Satisfaction

On the other hand, the variable of environmental responsibility had a significance value of 0.000 , which indicates that the variable has significantly positive impact on the satisfaction levels of employees; meanwhile the beta value has indicated that 1 unit change in environmental responsibilities can lead to 51.2 percent change in the overall satisfaction level of employees; whereas in the case of welfare, the significance value of 0.05 also indicates that the variable has significantly positive impact on the satisfaction levels of employees. In addition, the beta value has helped in understanding that 1 unit change in welfare responsibilities can lead to 19.9 percent change in the overall satisfaction level of employees.

\section{DISCUSSION}

This study makes a positive theoretical contribution to the relevant literature on CSR under COVID-19 Pandemic. First, although some studies have explored the impact of catastrophic (earthquakes, flash floods, among others) shocks on the operation of MNCs (Corey and Deitch 2011), COVID-19 has unique characteristics, primarily due to its long duration and large coverage area. Although Pandemic prevention measures such as lockdown have been effective in preventing its spread, they have also caused MNCs to suspend their operations to a certain extent. MNCs have faced operational difficulties in the past, but now, they face a crisis for survival. Thus, it is difficult to apply the conclusions of previous Pandemic research to COVID-19 situation. Besides, previous studies, from the of MNCs fulfilling their ICSR, that explore ways to change the situation of MNCs under an Pandemic are relatively scarce. Therefore, in the context of COVID-19, from the perspective of MNCs fulfilling

their ICSR, this study explores the impact of the ICSR disclosure of MNCs on employees satisfaction, which enriches the research results on enterprise crisis management. Second, this study proposes and demonstrates the mediating role of perceived enterprise self-sacrifice. On the one hand, previous research on selfsacrifice has focused on the impact of leaders' selfsacrifice on organizational behavior (de Cremer and van Knippenberg 2004; Jin and Lee 2019; Mulder and Nelissen 2010; Thomas et al. 2016) and the impact of selfsacrifice on partner relationships in the field of social psychology (Chantal and Mark 2003).

On the other hand, it has broadened the theoretical research perspective on the post-disaster psychological variables of social responsibility in the industry. In previous studies on CSR, scholars have already discussed the psychological consequences of perceived social responsibility (Farooq et al. 2014), enterprise identity (Story and Neves 2015), among others. However, the CSR of MNCs is mostly examined under major public events. The psychological mechanism of change has not attracted the attention of scholars. This study is based on the theory of selfsacrifice. Further, it verifies that under COVID-19, MNCs can actively fulfill their CSR. Employees perceive enterprise self-sacrifice and believe that enterprises have a noble morality and sense of responsibility, resulting in spillover effects that enhance the overall employees satisfaction. The findings of the study has helped in understanding the importance of CSR and its constructs on the satisfaction level of employees in the age of Covid- 
19, especially in reference to case of multinational corporations operating in United Arab Emirates. From the analysis and the overall study, it can be argued that corporate social responsibility means that the company must introduce several initiatives, not just for the purpose of economic benefits, but also for the well-being of its employees as well as other members in the society that goes beyond the minimum requirements as defined by the regulations and laws of countries.

This study eloborates that corporate social activities and performance during Pandemic can influence employee job satisfaction. In other words, there is considerable statistical evidence to support the notion that the mere fact that an organisation engages in social responsibility practices that serve the environment, community, and society has a positive effect on the job satisfaction of its employees. Employees analyse the actions of the organisation and what they perceive influences reaffirm or diminish their identity with it. The corporate social performance of an organisation indicates how much is being involved in social responsibility practices, which is perceived by its employees. This type of practice is perceived favourably because employees see it as a sign of social sensitivity in the company to which they belong. Therefore, corporate social performance is valued by its employees who respond positively to the organisation increasing their job satisfaction.

\section{Conclusion}

The practical contributions of this study mainly concern MNCs at the top level. First, fulfilling CSR is a rational choice for MNC's to find a new way out of difficulties. In the Internet era, the dispersal of information has changed, and the boundaries of organizations show "fuzziness. The Pandemic has had a great impact on the normal operation of MNC's, regarding the production or sales activities or the daily work of employees. MNC's need to respond actively, open resources, reduce expenditures, stabilize their cash flow, and ensure their survival in the Pandemic. Under circumstances where other factors are established, MNC's should actively fulfill their CSR and find new ways out of the predicament.

Second, paying attention to and implementing CSR in an Pandemic situation is conducive to establishing brand image and enhancing employees' job satisfaction and contentment. According to the findings of this study, under the impact of the Pandemic, MNC's face difficulties. Therefore, within their ability, MNC's need to protect employee interests first and actively fulfill their CSR to establish a good enterprise brand image. Such an image can help enterprises survive the Pandemic and usher in greater development opportunities after the Pandemic. The Pandemic has played a positive role in promoting forced change, and under such pressure, MNC's should actively fulfill their CSR, turning the threat into an opportunity.
Third, MNC's should promptly disclose their CSR activities to improve employees satisfaction level with their jobs. At the same time, MNC's should also pay attention to reasonable and effective publicity. According to the findings of this study, MNC's should publicize their CSR and objectively display their difficulties. They should fulfill their CSR and be aware of "good welfare" and "bad influence." Only by letting employees know the difficulties of the enterprise can they truly understand that the enterprise is sacrificing its interests to protect the interests of its employees, thus preventing public opinion in which people question that the enterprise blindly improves its internal welfare by neglecting its social responsibility, which is a show to deceive employees. Furthermore, this study found that philanthropic activities as a part of CSR policies in the times of Pandemic tend to enhance trust of employees in the company and its brands. It can be fairly assumed that employees consider relate to the philanthropic activities and consider own self as a part of the company that focuses on community betterment.

Fourth, a crisis management mechanism should be constructed, including the establishment of a plan, provision for a reserve fund system, and an early warning mechanism. Once a crisis occurs, MNC's can prepare and react quickly, and enterprise losses can be reduced to the minimum. This study also concludes that CSR activities of the companies with environmental responsibility tend to have a positive impact on employer brand specially in times of crisis. Companies are able to attract high quality talent with a perception that they are socially responsible employers. This study also concludes that reducing environmental footprints can work in favour of MNCs to keep their employees engaged with the business and its operations.

Furthermore, this study found that philanthropic activities as a part of CSR policies in the times of Pandemic tend to enhance trust of employees in the company and its brands. It can be fairly assumed that employees consider relate to the philanthropic activities and consider own self as a part of the company that focuses on community betterment.

\section{Future Research Recommendations}

This study has conducted a comprehensive quantitative design based study, however, there are certain limitations based on which this study makes recommendations for further research in the area of CSR and its impact on employees performance and satisfaction. Firstly, this study has focused on quantitative empirical evidence only and therefore it lacks qualitative evidence about how employees feel and perceive corporate CSR activities. Therefore future researchers are recommended to conduct qualitative design based studies. Furthermore, it is also recommended that future researchers involve more diverse stakeholders in the research process as this study involves on one stakeholder. Furthermore, this study also recommends that future researchers may endeavour to gather evidence regarding which CSR activities are best suited for the purpose of employee performance. 


\section{Limitations of the study}

One of the limitations of the study is that it's only being carried out in the context of the UAE that too only with 250 respondents, hence the study is limited regarding the region. Secondly, If future research can use panel data from CSR annual reports issued after the epidemic, it can be more intuitive to compare the impact of enterprises' ICSR on employees satisfaction level at different points before and after the epidemic. The sample size of the study is although small, but it is high for the sole researcher to manage. Therefore, the data analysis was needed to be done in a limited span of time. Finally, as the Pandemic has not yet ended, whether employees' satisfaction and positive attitudes toward enterprise actionss will translate into improved performance after the Pandemic still needs further research in the future.

\section{REFERENCES}

1. Adler, E.S. and Clark, R., 2014. An invitation to social research: How it's done. Nelson Education

2. Alegre, I., Mas-Machuca, M. and BerbegalMirabent, J., 2016. Antecedents of employee job satisfaction: Do they matter?. Journal of Business Research, 69(4), pp.1390-1395.

3. AlKahtani, N., Iqbal, S., Sohail, M., Sheraz, F., Jahan, S., Anwar, B., \& Haider, S. (2020). Impact of employee empowerment on organizational commitment through job satisfaction in four and five stars hotel industry. Management Science Letters, 11(3), 813-822.

4. Aparasu, R.R. and Bentley, J.P., 2014. Principles of research design and drug literature evaluation. Jones \& Bartlett Publishers.

5. Auer Antoncic, J. and Antoncic, B., 2011. Employee satisfaction, intrapreneurship and firm growth: a model. Industrial Management \& Data Systems, 111(4), pp.589-607.

6. Badke, W., 2017. Research strategies: Finding your way through the information fog. iUniverse.

7. Barkemeyer, R., 2011. Corporate perceptions of sustainability challenges in developed and developing countries: constituting a CSR divide?. Social Responsibility Journal, 7(2), pp. 257-281.

8. Bauman, C. W., \& Skitka, L. J. (2012). Corporate social responsibility as a source of employee satisfaction. Research in Organisational Behavior, 32, 63-86.

9. Bauman, C.W. and Skitka, L.J., 2012. Corporate social responsibility as a source of employee satisfaction. Research in Organisational Behaviour, 32, pp.63-86.

10. Bauman, C.W. and Skitka, L.J., 2012. Corporate social responsibility as a source of employee satisfaction. Research in Organisational Behaviour, 32, pp.63-86.

11. Baumann-Pauly, D., Wickert, C., Spence, L.J. and Scherer, A.G., 2013. Organising corporate social responsibility in small and large firms: Size matters. Journal of Business Ethics, 115(4), pp.693-705.

12. Beaudry, J.S. and Miller, L., 2016. Research literacy: A primer for understanding and using research. Guilford Publications.

13. Belal, A.R., 2016. Corporate social responsibility reporting in developing countries: The case of Bangladesh. Routledge.

14. Berad, N.R., 2011, March. Corporate Social Responsibility-Issues and Challenges in India. In International Conference on Technology and Business Management (pp. 28-30). Nasik: MET Institute of Management.

15. Berson, Y. and Linton, J.D., 2005. An examination of the relationships between leadership style, quality, and employee satisfaction in $R \& D$ versus administrative environments. R\&D Management, 35(1), pp.5160.

16. Bhattacharya, C.B., Korschun, D., Sen, S. and Routledge, H., 2017. Corporate Social Responsibility. Journal of International Law, 26(2).

17. Bryman, A., 2016. Social research methods. Oxford university press.

18. Cadbury, A., 2006. Corporate social responsibility. Twenty-First Century Society, 1(1), pp.5-21.

19. Carroll, A.B. and Shabana, K.M., 2010. The business case for corporate social responsibility: A review of concepts, research and practice. International journal of management reviews, 12(1), pp.85-105..

20. Carroll, A.B., 1991. The pyramid of corporate social responsibility: Toward the moral management of organisational stakeholders. Business horizons, 34(4), pp.39-48.

21. Carroll, A.B., 2015. Corporate social responsibility. Organisational dynamics, 44(2), pp.87-96.

22. Chen, S.H., Yang, C.C., Shiau, J.Y. and Wang, H.H., 2006. The development of an employee satisfaction model for higher education. the TQM Magazine, 18(5), pp.484-500.

23. Cheng, B., Ioannou, I. and Serafeim, G., 2014. Corporate social responsibility and access to finance. Strategic management journal, 35(1), pp.1-23.

24. Chi, C.G. and Gursoy, D., 2009. Employee satisfaction, customer satisfaction, and financial performance: An empirical examination. International Journal of Hospitality Management, 28(2), pp.245-253.

25. Chye Koh, H., \& Boo, E. F. H. (2004). Organisational ethics and employee satisfaction and commitment. Management Decision, 42(5), 677-693.

26. Cook, S. (2008). The essential guide to employee engagement: Better business performance 
through staff satisfaction. Kogan Page Publishers.

27. Crane, A. and Matten, D. eds., 2007. Corporate social responsibility (Vol. 2). Sage.

28. Crane, A., Matten, D. and Spence, L., 2013. Corporate social responsibility in a global context.

29. Crowther, D., 2008. Corporate social responsibility. Bookboon.

30. Darigan, K.H. and Post, J.E., 2009. Corporate Citizenship in China: CSR Challenges in the'Harmonious Society'. Journal of corporate citizenship, (35).

31. Dawkins, J. and Lewis, S., 2003. CSR in stakeholde expectations: And their implication for company strategy. Journal of Business Ethics, 44(2-3), pp.185-193.

32. Etikan, I., Musa, S.A. and Alkassim, R.S., 2016. Comparison of convenience sampling and purposive sampling. American Journal of Theoretical and Applied Statistics, 5(1), pp.1-4.

33. EwelUAEwa, U., 2015. Corporate Social Responsibility. The International Lawyer, 49, p. 179 .

34. Flammer, C., 2015. Does corporate social responsibility lead to superior financial performance? A regression discontinuity approach. Management Science, 61(11), pp. 2549-2568.

35. Freytag, P.V. and Young, L. eds., 2017. Collaborative Research Design: Working with Business for Meaningful Findings. Springer.

36. Grinstein, A. and Blekher, M., 2015. Corporate social responsibility. Wiley Encyclopedia of Management, pp.1-3.

37. Hair Jr, J.F., Wolfinbarger, M., Money, A.H., Samouel, P. and Page, M.J., 2015. Essentials of business research methods. Routledge.

38. Harreveld, B., Danaher, M., Lawson, C., Knight, B.A. and Busch, G. eds., 2016. Constructing Methodology for Qualitative Research: Researching Education and Social Practices. Springer.

39. Howell, K.E., 2012. An introduction to the philosophy of methodology. Sage.

40. Jabeen, S., Sheraz, F., Haider, S., Iqbal, S., Jahan, S., Tehseen, S. and Hussaini, T., 2021. The nexus between global disruption due to the covid-19 and performance of the construction project. Management Science Letters, pp.18711880.

41. Jahan, M. S., \& Martin, M. P. (2019). Exploring the Value of Your Website Analytics. EPRA International Journal of Economic and Business Review, (December), 66-69. https://doi.org/10.36713/epra2999.

42. Jahan, S., \& Alrajawy, I. (2020). Exploring the relationship between Corporate Social Responsibility ( CSR ) and Organisational Profitability-A study of the UAE Manufacturing
Industry. International Journal of Psychosocial Rehabilitation, 24(03), 5077-5087. https://doi.org/10.37200/IJPR/V2413/PR2021 129.

43. Jamali, D. and Karam, C., 2018. Corporate social responsibility in developing countries as an emerging field of study. International Journal of Management Reviews, 20(1), pp.32-61.

44. Johnson- Laird, P.N., 2006. Deductive reasoning. Encyclopedia of Cognitive Science.

45. Jones Christensen, L., Mackey, A. and Whetten, D., 2014. Taking responsibility for corporate social responsibility: The role of leaders in creating, implementing, sustaining, or avoiding socially responsible firm behaviours. Academy of Management Perspectives, 28(2), pp.164-178.

46. Jun, M., Cai, S. and Shin, H., 2006. TQM practice in maquiladora: Antecedents of employee satisfaction and loyalty. Journal of operations management, 24(6), pp.791-812.

47. Kelman, I., Loe, J.S.P., Rowe, E.W., Wilson, E., Fjærtoft, D.B., Poussenkova, N. and Nikitina, E., 2016. Corporate Social Responsibility.

48. Kesharwani, B. and Ravipati, T.B.P., 2015. Corporate Social Responsibility. Journal of Applied Management-Jidnyasa, 7(1), pp.2-4.

49. Kim, C. H., \& Scullion, H. (2013). The effect of Corporate Social Responsibility (CSR) on employee motivation: A cross-national study. Poznan university of economics review, 13(2).

50. Kitada, M. and Ölçer, A., 2015. Managing people and technology: The challenges in CSR and energy efficient shipping. Research in Transportation Business \& Management, 17, pp.36-40.

51. Lai, C.S., Chiu, C.J., Yang, C.F. and Pai, D.C., 2010. The effects of corporate social responsibility on brand performance: The mediating effect of industrial brand equity and corporate reputation. Journal of business ethics, 95(3), pp.457-469.

52. Lee, C. K., Song, H. J., Lee, H. M., Lee, S., \& Bernhard, B. J. (2013). The impact of CSR on casino employees' organisational trust, job satisfaction, and customer orientation: An empirical examination of responsible gambling strategies. International Journal of Hospitality Management, 33, 406-415.

53. Lee, Y.K., Lee, K.H. and Li, D.X., 2012. The impact of CSR on relationship quality and relationship outcomes: A perspective of service employees. International Journal of Hospitality Management, 31(3), pp.745-756.

54. Leonard, D. and McAdam, R., 2003. Corporate social responsibility. Quality progress, 36(10), p. 27.

55. Lim, J.S. and Greenwood, C.A., 2017. Communicating corporate social responsibility (CSR): Stakeholder responsiveness and 
engagement strategy to achieve CSR goals. Public Relations Review, 43(4), pp.768776.

56. Lindgreen, A. and Swaen, V., 2010. Corporate social responsibility. International Journal of Management Reviews, 12(1), pp.1-7.

57. Madlock, P.E., 2008. The link between leadership style, communicator competence, and employee satisfaction. The Journal of Business Communication (1973), 45(1), pp.61-78.

58. Manchanda, P., 2017. Corporate social Responsibility: Inventiveness by various enterprises. JIMS8M: The Journal of Indian Management \& Strategy, 22(3), pp.4-11.

59. Mansoor, A., Jahan, S. and Riaz, M. (2021). Does green intellectual capital spur corporate environmental performance through green workforce? Journal of Intellectual Capital. https://doi.org/10.1108/JIC-06-2020-0181

60. Martin, R.M., 2014. Epistemology: a beginner's guide. Oneworld Publications.

61. Matten, D. and Moon, J., 2004. Corporate social responsibility. Journal of business Ethics, 54(4), pp.323-337.

62. Matzler, K. and Renzl, B., 2006. The relationship between interpersonal trust, employee satisfaction, and employee loyalty. Total quality management and business excellence, 17(10), pp.1261-1271.

63. McWilliams, A., 2015. Corporate social responsibility. Wiley encyclopedia of management, pp.1-4.

64. Moon, J. and Knudsen, J.S., 2018, July. Corporate social responsibility and government. In Academy of Management Proceedings (Vol. 2018, No. 1, p. 12777). Briarcliff Manor, NY 10510: Academy of Management.

65. Morsing, M. and Perrini, F., 2009. CSR in MNCs: do MNCs matter for the CSR agenda?. Business Ethics: A European Review, 18(1), pp.1-6.

66. Ni, A. and Van Wart, M., 2015. Corporate Social Responsibility: Doing Well and Doing Good. In Building Business-Government Relations (pp. 175-196). Routledge.

67. Nazar, N.; Jahan, S.; Amoozegar, A.; Anjum, T.; Raju, V. (2020).The effects of total quality management practices on corporate social responsibility using supply chain model: A review of Malaysian hotel industry. International Journal of Supply Chain Managament, 9, pp. 294-304.

68. Parsons, B. ed., 2015. John Calvin: A Heart for Devotion, Doctrine, Doxology. Blackstone Audio, Incorporated.

69. Parvin, M.M. and Kabir, M.N., 2011. Factors affecting employee job satisfaction of pharmaceutical sector. Australian journal of business and management research, 1(9), p.113.

70. Patten, M.L. and Newhart, M.,
2017. Understanding research methods: An overview of the essentials. Taylor \& Francis.

71. Pedersen, E.R.G. ed., 2015. Corporate social responsibility. Sage.

72. Portney, P.R., 2005. Corporate social responsibility. Environmental Protection and the Social Responsibility of Firms-Perspectives from Law, Economics, and Business.

73. Rettab, B., Brik, A.B. and Mellahi, K., 2009. A study of management perceptions of the impact of corporate social responsibility on organisational performance in emerging economies: the case of Dubai. Journal of Business Ethics, 89(3), pp.371-390.

74. Rogelberg, S.G., Allen, J.A., Shanock, L., Scott, C. and Shuffler, M., 2010. Employee satisfaction with meetings: A contemporary facet of job satisfaction. Human Resource Management: Published in Cooperation with the School of Business Administration, The University of Michigan and in alliance with the Society of Human Resources Management, 49(2), pp.149172.

75. Rosenberg, G.N., 2017. Positivism, interpretivism, and the study of law. In Law and Social Movements (pp. 33-53). Routledge.

76. Roy, S.K., Roy, S., Mubeen, R., Brindha, N., Abirami, A., Leve, S.L., Mohanraju, B.L., Priyadarshini, K., Jeyabharathy, P., Thilakam, C. and Mahadevi, S., 2015. Corporate social responsibility. EduPedia Publications Pvt. Ltd..

77. Saeidi, S.P., Sofian, S., Saeidi, P., Saeidi, S.P. and Saaeidi, S.A., 2015. How does corporate social responsibility contribute to firm financial performance? The mediating role of competitive advantage, reputation, and customer satisfaction. Journal of business research, 68(2), pp.341-350.

78. Schneider, A. and Schmidpeter, R., 2012. Corporate social responsibility. Verantwortliche Unternehmensführung in der Praxis, Berlin ua.

79. Schrempf-Stirling, J., Palazzo, G. and Phillips, R.A., 2016. Historic corporate social responsibility. Academy of Management Review, 41(4), pp.700-719.

80. Sekaran, U., \& Bougie, R. (2016). Research methods for business: A skill building approach. John Wiley \& Sons.

81. Sharma, S., Sharma, J., \& Devi, A. (2009). Corporate social responsibility: the key role of human resource management. Business Intelligence Journal, 2(1), 205-213.

82. Singhapakdi, A., Lee, D.J., Sirgy, M.J. and Senasu, K., 2015. The impact of incongruity between an organisation's CSR orientation and its employees' CSR orientation on employees' quality of work life. Journal of Business Research, 68(1), pp.60-66.

83. Skudiene, V., \& Auruskeviciene, V. (2012). The contribution of corporate social responsibility to 
internal employee motivation. Baltic journal of management, 7(1), 49-67.

84. Smart, J.J.C., 2014. Philosophy and scientific realism. Routledge.

85. Smith, A.M., 2012. Research methodology: A step-by-step guide for beginners. Nurse Education in Practice, 12(3), p.e25.

86. Steenkamp, J.B., 2017. Corporate Social Responsibility. In Global Brand Strategy (pp. 209-238). Palgrave Macmillan, London.

87. Stuhr, J.J., 2015. Pragmatism, postmodernism and the future of philosophy. Routledge.

88. Suliman, A.M., Al-Khatib, H.T. and Thomas, S.E., 2016. Corporate social responsibility. Corporate Social Performance: Reflecting on the Past and Investing in the Future, p.15.

89. Tai, F.M. and Chuang, S.H., 2014. Corporate social responsibility. Ibusiness, 6(03), p.117.

90. Vinerean, S., Cetină, I., Dumitrescu, L., \& Ț ichindelean, I. (2013). Modelling employee engagement in relation to CSR practices and employee satisfaction. Revista Economica, 65(1), 21-37.

91. Vlachos, P. A., Panagopoulos, N. G., \& Rapp, A. A. (2013). Feeling good by doing good: Employee CSR-induced attributions, job satisfaction, and the role of charismatic leadership. Journal of business ethics, 118(3), 577-588.

92. Vlachos, P.A., Panagopoulos, N.G. and Rapp, A.A., 2013. Feeling good by doing good: Employee CSR-induced attributions, job satisfaction, and the role of charismatic leadership. Journal of business ethics, 118(3), pp.577-588.

93. Wang, H., Tong, L., Takeuchi, R. and George, G., 2016. Corporate social responsibility: An overview and new research directions: Thematic issue on corporate social responsibility.

94. Weber, J. and Wasieleski, D.M. eds., 2018. Corporate social responsibility. Emerald Group Publishing.

95. Zentes, J., Morschett, D. and Schramm-Klein, H., 2017. Corporate social responsibility. In Strategic retail management(pp. 207-226). Springer Gabler, Wiesbaden.

96. Zhu, D. and Tan, K.H., 2008. Issues and challenges of CSR practices in textile industry: an empirical study in Suzhou, China. International Journal of Management and Enterprise Development, 5(6), pp.759-772. 